\title{
Effect of Temperature on Conidial Germination of Botryosphaeriaceae Species Infecting Grapevines
}

\author{
José R. Úrbez-Torres, Department of Plant Pathology, University of California, Davis 95616, USA; Emilie Bruez, \\ UMR Santé Végétale 1065, INRA, ENITA de Bordeaux, Institut des Sciences de la Vigne et du Vin, Villenave \\ d'Ornon Cedex, 33883, France; and José Hurtado and Walter D. Gubler, Department of Plant Pathology, Univer- \\ sity of California, Davis 95616, USA
}

\begin{abstract}
Úrbez-Torres, J. R., Bruez, E., Hurtado, J., and Gubler, W. D. 2010. Effect of temperature on conidial germination of Botryosphaeriaceae species infecting grapevines. Plant Dis. 94:14761484.

Germination of conidia of eight botryosphaeriaceous fungi infecting grapevines was evaluated after 2, 4, 6, 12, and $24 \mathrm{~h}$ incubation under eight different temperatures $(5,10,15,20,25,30,35$, and $40^{\circ} \mathrm{C}$ ). The effect of temperature on conidial germination was also evaluated in different stages (hyaline versus pigmented conidia) of the species Lasiodiplodia theobromae. Conidial germination of Botryosphaeriaceae species infecting grapevines was significantly affected by temperature. Overall, conidial germination increased significantly with longer incubation times, especially from 2 to $12 \mathrm{~h}$. In most cases, germination of conidia was not significantly different between 12 and $24 \mathrm{~h}$ incubation. Conidia of botryosphaeriaceous species did not germinate (with the exception of Botryosphaeria dothidea and Neofusicoccum parvum) at $5^{\circ} \mathrm{C}$, and only $\mathrm{B}$. dothidea, Diplodia seriata, and L. theobromae showed high levels of conidial germination at $40^{\circ} \mathrm{C}$. Optimum conidial germination temperatures (defined as the temperature in which germination reached at least $50 \%$ in the shortest incubation time) were $25^{\circ} \mathrm{C}$ for $B$. dothidea and Dothiorella iberica, 25 to $30^{\circ} \mathrm{C}$ for Spencermartinsia viticola, $30^{\circ} \mathrm{C}$ for Diplodia corticola, D. mutila, D. seriata, $N$. parvum, and hyaline $L$. theobromae, and $40^{\circ} \mathrm{C}$ for pigmented $L$. theobromae conidia. Successful conidial germination of species of Botryosphaeriaceae infecting grapevines was always observed between 10 and $35^{\circ} \mathrm{C}$ with the exception of Dothiorella iberica and pigmented L. theobromae conidia, neither of which germinated at 35 and $10^{\circ} \mathrm{C}$, respectively. Results of this study show conidia of botryosphaeriaceous species infecting grapevines to be capable of germination under a broad range of temperatures including those considered to be extreme, which may explain the success of these species as grapevine pathogens throughout most of the grapegrowing areas in both Northern and Southern Hemispheres.
\end{abstract}

Botryosphaeriaceae Theiss. \& P. Syd. is a species-rich family with 26 genera (www.MycoBank.org). Species in the family Botryosphaeriaceae are found worldwide and are saprophytic, endophytic, and parasitic in a wide range of both annual and perennial host plants $(2,27)$. Several botryosphaeriaceous species are wellknown pathogens of woody perennial plants causing significant economic losses in important crops including pome and stone fruit trees $(5,26)$, blueberry $(7,18)$, pistachio (15), almond (10), avocado (14), and grapevines $(33,41)$. To date, 15 species in the Botryosphaeriaceae, placed in the anamorphic genera Diplodia Fr., Dothiorella Sacc., Fusicoccum Corda, Lasiodiplodia Ellis \& Everh, Neofusicoccum Crous, Slippers \& A.J.L. Phillips, and Spencermartinsia A.J.L. Phillips, A. Alves \&

Corresponding author: Walter D. Gubler

E-mail: wdgubler@ucdavis.edu

Accepted for publication 24 August 2010.

doi:10.1094/PDIS-06-10-0423

(C) 2010 The American Phytopathological Society
Crous, have been recognized to be pathogenic on grapes $(31,33,39-41)$. Species of Botryosphaeriaceae infecting grapevines cause a broad variety of disease symptoms including light brown discoloration of the wood, dark wood streaking, bud necrosis, graft failure, cane bleaching, perennial cankers, and bunch rot $(13,20,21,38,44)$. Significant economic losses to the grapevine industry as a result of Botryosphaeriaceae species infection have been reported in the southeastern United States and California $(17,25)$.

Conidia, produced in pycnidia located in different parts of the vine (old pruning wounds, dead tissue of spurs, cordons, and trunk, embedded in the bark and in pruning debris left on the vineyard floor), are the primary propagules of Botryosphaeriaceae in vineyards. Additionally, pycnidia of species of Botryosphaeriaceae have been reported to occur in a wide range of other hosts surrounding vineyards $(4,10)$. Seasonal patterns of conidial release have been shown to vary from one grapevinegrowing region to another; however, conidial release has always been shown to be correlated with rain events $(12,24,32)$. Conidia are rain splash dispersed and in- fect grapevines primarily through pruning wounds. Úrbez-Torres and Gubler (34) presented evidence that pruning wound infections by species of Botryosphaeriaceae occur mainly during the dormant season in California, especially when vines were pruned from November to January. In a similar study conducted in Italy, conidia of Diplodia seriata De Not. were shown to infect grapevine pruning wounds up to late spring/early summer (24). Consequently, it is likely that Botryosphaeriaceae spores germinate and infect grapevines under a wide range of different environmental conditions including temperature.

Temperature is known to play a critical role in germination of most fungal spores. Consequently, the effect of temperature on spore germination of fungal pathogens has been widely studied in order to determine the necessary conditions for fungal infection. Moreover, knowledge of various spore reactions to temperature has been shown to significantly improve both disease prediction models and management options in many different crops $(3,9,11,16,19,29)$. The effect of temperature on germination of both ascospores and conidia of Botryosphaeria dothidea (Moug. ex Fr.) Ces. \& De Not. and $D$. seriata causing white and black rot, frogeye leaf spot, and limb canker of apples has been widely studied $(1,28)$. However, the precise influence of temperature on conidial germination of species of Botryosphaeriaceae infecting grapevines has not yet been investigated. Knowledge of both optimum and range of temperatures in which Botryosphaeriaceae conidia germinate will result in a better understanding of their biology and disease epidemiology. Accordingly, this information will improve the development and implementation of more efficient management techniques for grapevine diseases caused by Botryosphaeriaceae. Thus, the objective of this study was to determine the effect of temperature on conidial germination of at least one species of each of the Botryosphaeriaceae genera infecting grapevines.

\section{MATERIALS AND METHODS}

This study included 20 isolates of eight different species representing all botryosphaeriaceous genera infecting grapevines (Table 1). Isolates were obtained from grapevine cankers from previous studies, 
identified by means of both morphological characters and molecular analyses, and stored at the Plant Pathology Department, University of California Davis, fungal collection $(31,34,35,38)$. Isolates were maintained on $4 \%$ potato dextrose agar (PDA) (Difco Laboratories, Detroit, MI) mycelial plugs in glass vials with sterile water at $4^{\circ} \mathrm{C}$ until use. Mycelium of each isolate was recovered from our collection after plating of a mycelial plug on PDA petri dishes amended with tetracycline hydrochloride $(0.01 \%)$ (Sigma-Aldrich, St Louis, MO) (PDA-tet). Petri dishes were incubated at room temperature $\left(24 \pm 2^{\circ} \mathrm{C}\right)$ for 10 days. Fungal isolates then were transferred to new 9-cm-diameter PDA petri dishes and incubated at room temperature under a 12-h light-and-dark cycle of cool-white fluorescent light until pycnidia were formed. In order to enhance pycnidia formation of the Neofusicoccum parvum (Pennycook \& Samuels) Crous, Slippers \& A.J.L. Phillips isolates UCD642So and UCD1125Na, mycelial plugs were additionally placed onto $2 \%$ water agar (WA) (Difco) in 9-cm-diameter petri dishes containing autoclaved pine needles.

Conidia of the different species were obtained by collecting pycnidia formed in cultures and separately placing them in $1.5-\mathrm{ml}$ sterile microcentrifuge tubes. Pycnidia were crushed in sterile distilled water using a sterile plastic pestle. Water containing conidia was filtered through four layers of cheesecloth to remove mycelial and pycnidia fragments. The resulting conidial suspension was quantified with a hemacytometer, and thereafter was diluted to a final concentration of approximately
50 conidia per microliter. For each isolate, four $1-\mu \mathrm{l}$ drops of conidial suspension were placed onto 9-cm-diameter PDA petri dishes as described by Inman et al. (11). Inoculated petri dishes were placed in temperature-controlled incubators set at 5, $10,15,20,25,30,35$, and $40^{\circ} \mathrm{C}$ and removed at 2, 4, 6, 12, and $24 \mathrm{~h}$ thereafter to quantify spore germination. As soon as petri dishes were removed from the incubators, $2 \mu \mathrm{l}$ of aniline blue dye was deposited onto each group of conidia, and plates were stored at $4^{\circ} \mathrm{C}$ until the stain was fully absorbed. Afterward, conidia were examined microscopically at $\times 40$ magnification to determine the percentage of germinated conidia. Percent spore germination was determined by observing 50 conidia selected randomly from each drop. Conidia were counted as germinated when the length of the germ tube was at least onehalf the length of the spore. The experiment was repeated twice.

A separate experiment was conducted to determine the effect of temperature on germination of hyaline conidia of Lasiodiplodia theobromae (Pat.) Griff. \& Maubl. In this study, L. theobromae conidia from the different isolates were harvested from pycnidia when hyaline (before development of septa, pigmentation, and striations), when cultures were approximately 14 days old. Spore germination of hyaline $L$. theobromae conidia was determined as described above. The experiment was repeated twice.

All statistical analyses were performed using SAS (Version 9.2; SAS Institute, Cary, NC). Spore germination percentages were arcsine square root transformed prior to analyses. The significance of differences on conidial germination among species and isolates was tested with analysis of variance (ANOVA) using the SAS PROC Mixed procedure. The effects of isolate, time, and temperature on germination were assessed using a linear mixed effects model for each species separately. Isolate, time, temperature, and all their interactions were treated as fixed effects. Experiment and experiment crossed with all fixed effects were treated as random effects. Replication was treated as a random effect, nested in the four-way interaction of experiment, isolate, time, and temperature. This resulted in a conservative analysis for the main effects. Model fit was assessed via graphical analysis of residuals and the Shapiro-Wilk test for normality. The effects of outliers were assessed by performing the analysis with and without residuals. Pairwise comparisons between times within temperatures were made using the Tukey-Kramer correction test at the 5\% significance level. Germination data of each Botryosphaeriaceae species were analyzed using linear regression to determine optimum conidial germination temperature. Optimum temperature was defined as the temperature in which germination reached $50 \%$ in the shortest incubation time. First- and second-order polynomials were fit to the data, and $R^{2}$ values were examined to find curves that best fit the data.

\section{RESULTS}

Spore germination data from two separate experiments were not significantly different $(F=1.07, P=0.3157)$, and thus data from both experiments were combined in the analyses. There were no sig-

Table 1. Botryosphaeriaceae species isolates used in this study

\begin{tabular}{|c|c|c|c|c|c|c|}
\hline \multirow[b]{2}{*}{ Isolate } & \multirow[b]{2}{*}{ Species } & \multirow[b]{2}{*}{ Geographic origin } & \multicolumn{4}{|c|}{ GenBank accession no. } \\
\hline & & & ITS $^{\mathbf{a}}$ & $\beta$-tubulin ${ }^{b}$ & EF1- $\alpha^{\mathrm{c}}$ & Collection no. $^{d}$ \\
\hline UCD1064So & Botryosphaeria dothidea & Sonoma County, CA & DQ233600 & DQ233621 & GU294733 & UCD1064So \\
\hline UCD1333So & Botryosphaeria dothidea & Sonoma County, CA & DQ008327 & DQ008350 & GU294736 & UCD1333So \\
\hline UCD1672Yo & Botryosphaeria dothidea & Yolo County, CA & DQ233603 & DQ233624 & GU294737 & MYA-3710 \\
\hline UCD1260So & Diplodia corticola & Sonoma County, CA & GU799470 & GU799464 & GU799467 & UCD1260So \\
\hline UCD1275So & Diplodia corticola & Sonoma County, CA & GU799471 & GU799465 & GU799468 & UCD1275So \\
\hline UCD2397TX & Diplodia corticola & Gillespie County, TX & FJ790842 & GU294724 & GU294710 & UCD2397TX \\
\hline UCD288Ma & Diplodia mutila & Madera County, CA & DQ008313 & DQ008336 & EU012411 & UCD288Ma \\
\hline UCD1965SB & Diplodia mutila & Santa Barbara County, CA & DQ233599 & DQ233620 & EU012414 & MYA-3697 \\
\hline $\mathrm{UCD} 244 \mathrm{Ma}$ & Diplodia seriata & Madera County, CA & DQ008314 & DQ008337 & EU012406 & MYA-3692 \\
\hline UCD352Mo & Diplodia seriata & Monterey County, CA & DQ008315 & DQ008338 & EU012407 & MYA-3693 \\
\hline UCD1439SLO & Dothiorella iberica & San Luis Obispo County, CA & EF202008 & EF202015 & EF202022 & CBS121001 \\
\hline UCD1448SLO & Dothiorella iberica & San Luis Obispo County, CA & EF202009 & EF202016 & EF202023 & CBS121002 \\
\hline UCD191Co & Lasiodiplodia theobromae & Riverside County, CA & DQ008308 & DQ008331 & EU012397 & UCD191Co \\
\hline UCD205Co & Lasiodiplodia theobromae & Riverside County, CA & DQ008310 & DQ008334 & EU012398 & MYA-3689 \\
\hline UCD256Ma & Lasiodiplodia theobromae & Madera County, CA & DQ233594 & DQ233615 & GU294742 & UCD256Ma \\
\hline UCD642So & Neofusicoccum parvum & Sonoma County, CA & DQ008328 & DQ008351 & GU294741 & MYA-3705 \\
\hline $\mathrm{UCD} 1125 \mathrm{Na}$ & Neofusicoccum parvum & Napa County, CA & DQ233612 & DQ233633 & GU294740 & $\mathrm{UCD} 1125 \mathrm{Na}$ \\
\hline UCD3So & Spencermartinsia viticola & Sonoma County, CA & EF202013 & EF202020 & EF202027 & CBS120999 \\
\hline UCD1435SLO & Spencermartinsia viticola & San Luis Obispo County, CA & EF202007 & EF202014 & EF202021 & MYA-4112 \\
\hline UCD1642Yo & Spencermartinsia viticola & Yolo County, CA & EF202010 & EF202017 & EF202024 & CBS121000 \\
\hline
\end{tabular}


nificant differences among isolates of $B$. dothidea, Diplodia corticola A.J.L. Phillips, Alves \& Luque, Diplodia mutila Fr. in Mont., $N$. parvum, and L. theobromae for any of the temperature response parameters and incubation times (Table 2). Consequently, germination rates shown in Figures 1 and 2 represent the mean of the
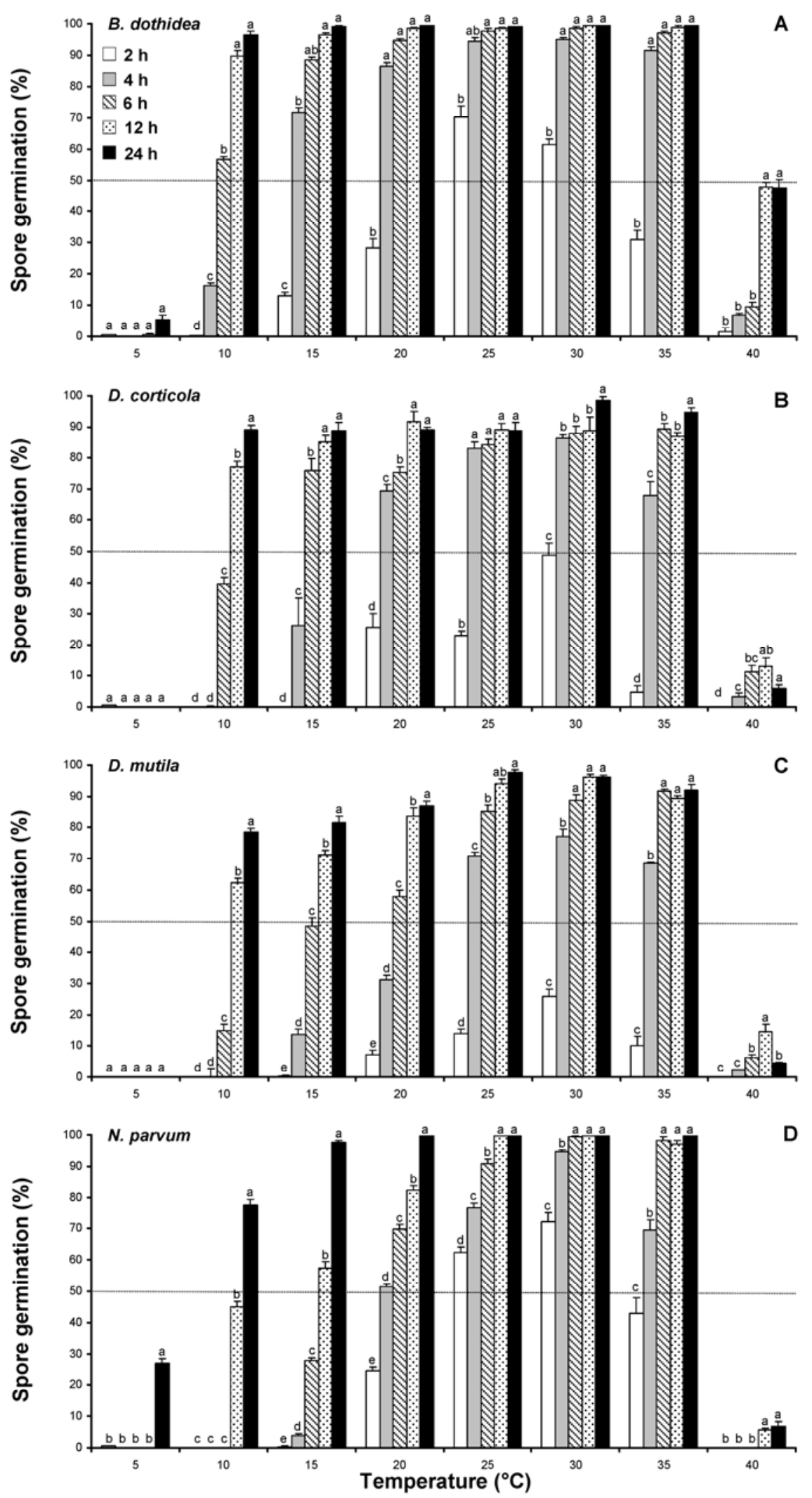

Fig. 1. Effect of temperature on conidial germination of A, Botryosphaeria dothidea, B, Diplodia corticola, C, Diplodia mutila, and D, Neofusicoccum parvum after 2, 4, 6, 12, and $24 \mathrm{~h}$ of incubation. Bars represent standard error of the mean. Means with the same letter are not significantly different at the 0.05 level. Dotted line represents $50 \%$ germination.

different isolates tested for each of those species of Botryosphaeriaceae. Statistical analyses showed significant differences among isolates of $D$. seriata, Dothiorella iberica A.J.L. Phillips, Luque \& Alves, and Spencermartinsia viticola A.J.L. Phillips \& Luque (Table 2). Consequently, germination rates shown in Figures 3, 4, and 5 represent each isolate tested for those species of Botryosphaeriaceae. The effect of temperature and incubation time on conidial germination of each species was highly significant (Table 2). At $5^{\circ} \mathrm{C}$, overall results showed no conidial germination for either Diplodia or Lasiodiplodia species. At $5^{\circ} \mathrm{C}, 4.9$ and $13.7 \%$ germination was observed after $24 \mathrm{~h}$ for Dothiorella iberica and $S$. viticola isolates UCD1439SLO and UCD1435SLO, respectively (Figs. 4A and 5B), and 5.2 and $26.9 \%$ after $24 \mathrm{~h}$ for $B$. dothidea and $N$. parvum, respectively. Conidia from all Botryosphaeriaceae species studied germinated to some extent at $40^{\circ} \mathrm{C}$. However, percent conidial germination from $B$. dothidea, D. seriata, and $L$. theobromae was significantly higher than the rest of the species at $40^{\circ} \mathrm{C}$. Percent conidial germination of each species generally increased significantly with longer incubation times when temperatures were equal to and/or above $10^{\circ} \mathrm{C}$ (Figs. 1 to 5). At $10^{\circ} \mathrm{C}$ and above and for all species studied, the greatest increase in conidial germination generally was observed between 2 and 12 $\mathrm{h}$ incubation time. At low temperatures (10 and $15^{\circ} \mathrm{C}$ ), some species, including $N$. parvum, L. theobromae (hyaline), Dothiorella iberica, and $S$. viticola, showed a significant increase in conidial germination up to $24 \mathrm{~h}$ incubation (Figs. 1 to 3 and 5); however, percent germination in most cases was not significantly different between 12 and $24 \mathrm{~h}$ incubation times (Figs. 1 to 5$)$.

Approximately $56 \%$ of the conidia of $B$. dothidea germinated at $10^{\circ} \mathrm{C}$ after $6 \mathrm{~h}$, and more than $80 \%$ germination occurred after $12 \mathrm{~h}$ (Fig. 1A). Over $80 \%$ of conidia of $B$. dothidea germinated between 15 and $35^{\circ} \mathrm{C}$ after $4 \mathrm{~h}$ incubation. Over $50 \%$ conidial germination of $B$. dothidea was observed at both 25 and $30^{\circ} \mathrm{C}$ after only $2 \mathrm{~h}$ incubation. Regression analyses showed $25^{\circ} \mathrm{C}$ to be the temperature at which $50 \%$ germination was reached in the shortest incubation time $\left(1.7 \mathrm{~h}, r^{2}=0.9267\right)$.

Conidia of D. corticola showed $77 \%$ germination at $10^{\circ} \mathrm{C}$ after $12 \mathrm{~h}$. Over $50 \%$ germination of conidia of $D$. corticola was observed after $6 \mathrm{~h}$ at $15^{\circ} \mathrm{C}$ and after $4 \mathrm{~h}$ between 20 and $35^{\circ} \mathrm{C}$. Approximately 98 and $95 \%$ of conidia germinated at 30 and $35^{\circ} \mathrm{C}$, respectively, after $24 \mathrm{~h}$ incubation (Fig. 1B). Regression analyses showed $30^{\circ} \mathrm{C}$ to be the temperature at which $50 \%$ germination was reached in the shortest incubation time $\left(2.2 \mathrm{~h}, r^{2}=0.9941\right)$. More than 50 and $80 \%$ D. mutila conidia germinated between 25 and $35^{\circ} \mathrm{C}$ after 4 and $6 \mathrm{~h}$, 
respectively (Fig. 1C). Based on regression analyses, optimum temperature for conidial germination of D. mutila was $30^{\circ} \mathrm{C}$. At this temperature, $50 \%$ germination was reached in the shortest incubation time (3.12 h, $\left.r^{2}=0.9507\right)$.

Approximately 62 and $72 \%$ of the conidia of $N$. parvum germinated after $2 \mathrm{~h}$ at 25 and $30^{\circ} \mathrm{C}$, respectively (Fig. 1D). After $4 \mathrm{~h}$ incubation, over $50 \%$ conidial germination of $N$. parvum was observed between 20 and $35^{\circ} \mathrm{C}$. Over $98 \%$ conidial germination of $N$. parvum was reached after $24 \mathrm{~h}$ at 15 and $20^{\circ} \mathrm{C}$, after $12 \mathrm{~h}$ at $25^{\circ} \mathrm{C}$, and after $6 \mathrm{~h}$ at 30 and $35^{\circ} \mathrm{C}$ (Fig. 1D). Regression analyses showed $30^{\circ} \mathrm{C}$ to be the temperature at which $50 \%$ germination was reached in the shortest incubation time (1.9 $\mathrm{h}, r^{2}=0.8123$ ).

L. theobromae pigmented and septate conidia needed temperatures of $20^{\circ} \mathrm{C}$ and above in order to reach over $50 \%$ germination (Fig. 2A). After $4 \mathrm{~h}$ incubation, over $50 \%$ of pigmented and septate conidia germinated between 25 and $40^{\circ} \mathrm{C}$. Over $80 \%$ conidial germination was reached after $12 \mathrm{~h}$ at 25 and $30^{\circ} \mathrm{C}$ and after $6 \mathrm{~h}$ at 35 and $40^{\circ} \mathrm{C}$ (Fig. 2A). The shortest incubation time to reach at least $50 \%$ of $L$. theobromae pigmented and septate conidial germination was observed at $40^{\circ} \mathrm{C}$ (3.87 h, $\left.r^{2}=0.9377\right)$ but was not significantly different $(P=0.2239)$ from the incubation time observed at $35^{\circ} \mathrm{C}(3.91 \mathrm{~h}$, $\left.r^{2}=0.9232\right)$. L. theobromae hyaline and unicellular conidia reached $50 \%$ germination at lower temperatures $\left(10\right.$ and $\left.15^{\circ} \mathrm{C}\right)$ than the pigmented and septated conidia, and after $4 \mathrm{~h}$ incubation $50 \%$ germination or more was observed between 20 and $40^{\circ} \mathrm{C}$ (Fig. 2B). Over $80 \%$ hyaline and unicellular conidial germination was reached after $12 \mathrm{~h}$ at $15^{\circ} \mathrm{C}$ and after $6 \mathrm{~h}$ between 20 and $40^{\circ} \mathrm{C}$ (Fig. 2B). The shortest incubation time to reach at least $50 \%$ of L. theobromae hyaline and unicellular conidial germination was observed at $30^{\circ} \mathrm{C}$ (2.58 h, $\left.r^{2}=0.9227\right)$.

Conidia of both $D$. seriata isolates UCD244Ma and UCD352Mo showed over $50 \%$ germination after $6 \mathrm{~h}$ at $10^{\circ} \mathrm{C}$ (Fig. 3). Over $50 \%$ germination was observed after $2 \mathrm{~h}$ between 20 and $35^{\circ} \mathrm{C}$ and between 25 and $35^{\circ} \mathrm{C}$ for isolates UCD244Ma and UCD352Mo, respectively. Over $80 \%$ germination of conidia of $D$. seriata was observed after $4 \mathrm{~h}$ between 25 and $35^{\circ} \mathrm{C}$ and between 20 and $35^{\circ} \mathrm{C}$ for isolates UCD244Ma and UCD352Mo, respectively (Fig. 3). For isolate UCD244Ma, approximately 63,85 , and $87 \%$ of conidia germinated at $40^{\circ} \mathrm{C}$ after 6,12 , and $24 \mathrm{~h}$ incubation, respectively (Fig. 3A). For isolate UCD352Mo, approximately 73, 80, 83, and $75 \%$ of conidia germinated at $40^{\circ} \mathrm{C}$ after $4,6,12$, and $24 \mathrm{~h}$ incubation, respectively (Fig. 3B). Regression analyses showed $30^{\circ} \mathrm{C}$ to be the temperature at which $50 \%$ germination was reached in the shortest incubation time for both
UCD244Ma (1.76 h, $\left.r^{2}=0.8789\right)$ and UCD352Mo $\left(1.87 \mathrm{~h}, r^{2}=0.7341\right)$.

Conidia of Dothiorella iberica needed $24 \mathrm{~h}$ incubation to reach more than $50 \%$ germination at $10^{\circ} \mathrm{C}$ and over $12 \mathrm{~h}$ at 15 , 20, and $30^{\circ} \mathrm{C}$ (Fig. 4). In both Dothiorella iberica isolates studied, conidial germination increased significantly from $2 \mathrm{~h}$ ( $<10 \%$ conidia germinated) to $24 \mathrm{~h}(>90 \%$ conidia germinated) between 15 and $30^{\circ} \mathrm{C}$. Isolate UCD1439SLO showed slightly higher spore germination at both 35 and $40^{\circ} \mathrm{C}$ than isolate UCD1448SLO. Regression analyses showed $25^{\circ} \mathrm{C}$ to be the temperature at which $50 \%$ germination was reached in the shortest incubation time for both UCD1439SLO $\left(5.83 \mathrm{~h}, r^{2}=0.8633\right)$ and UCD1448SLO (4.75 h, $\left.r^{2}=0.8317\right)$ isolates.

Conidial germination of S. viticola varied significantly among the isolates studied. Over $50 \%$ conidial germination was observed after $4 \mathrm{~h}$ between 25 and $30^{\circ} \mathrm{C}$ and between 20 and $30^{\circ} \mathrm{C}$ for isolate UCD3So and UCD1435SLO and UCD1642Yo, respectively (Fig. 5). Isolate UCD3So reached over $80 \%$ conidial germination after $24 \mathrm{~h}$ at 10 and $15^{\circ} \mathrm{C}$, after $12 \mathrm{~h}$ at $20^{\circ} \mathrm{C}$, and after $6 \mathrm{~h}$ at 25 and $30^{\circ} \mathrm{C}$ (Fig. 5A). Isolate UCD1435SLO reached over $80 \%$ conidial germination after $24 \mathrm{~h}$ at $10^{\circ} \mathrm{C}$, after $12 \mathrm{~h}$ at 15 and $20^{\circ} \mathrm{C}$, and after $6 \mathrm{~h}$ at $30^{\circ} \mathrm{C}$ (Fig. 5B). Isolate
UCD1642Yo reached over $80 \%$ conidial germination after $24 \mathrm{~h}$ at $10^{\circ} \mathrm{C}$, after $12 \mathrm{~h}$ at $15^{\circ} \mathrm{C}$, and after $6 \mathrm{~h}$ at 20,25 , and $30^{\circ} \mathrm{C}$ (Fig. 5C). Conidial germination did not reach more than $75 \%$ at $35^{\circ} \mathrm{C}$ in all isolates studied, and only isolate UCD1435SLO showed conidial germination at $40^{\circ} \mathrm{C}$ (Fig. 5B). Based on regression analyses, optimum temperature at which $50 \%$ conidial germination of $S$. viticola was reached in the shortest incubation time was not significantly different between 25 and $30^{\circ} \mathrm{C}$ for all isolates studied: UCD3So (3.03 h, $\left.r^{2}=0.9101\right)$, UCD1435SLO (2.89 $\left.\mathrm{h}, r^{2}=0.7342\right)$, and UCD1642Yo $\left(2.6 \mathrm{~h}, r^{2}\right.$ $=0.6522$ ).

\section{DISCUSSION}

Species of Botryosphaeriaceae have recently gained importance as grapevine pathogens worldwide, and consequently, interest has risen significantly in understanding their biology, epidemiology, and mode of infection in order to develop and implement efficient chemical, cultural, and organically acceptable control methods. Species of Botryosphaeriaceae infect grapevines by means of conidia, primarily through pruning wounds. Although the effect of temperature on mycelium growth has been studied on species of Botryosphaeriaceae infecting grapevines (38), little information was available regarding
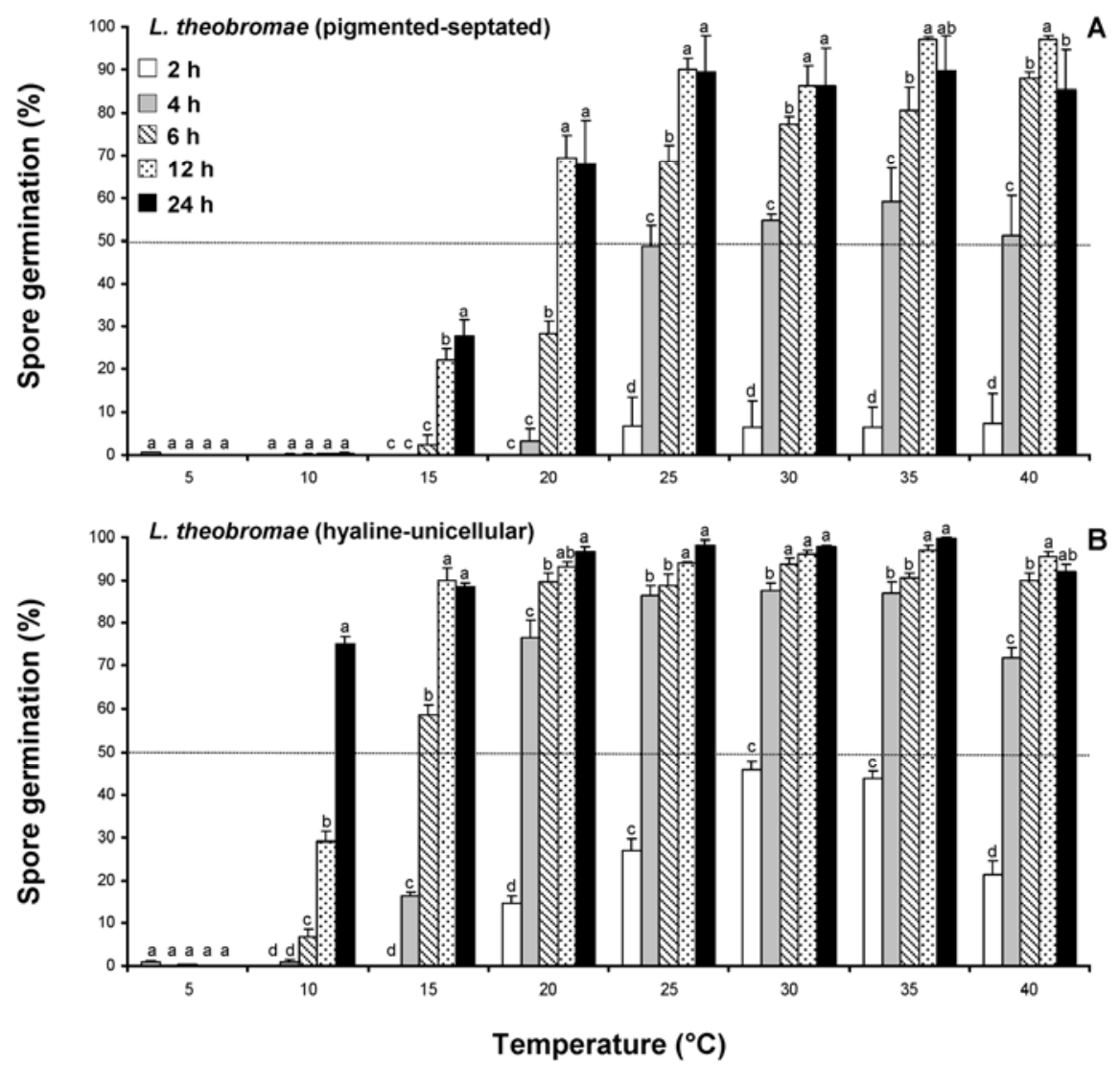

Fig. 2. Effect of temperature on $\mathbf{A}$, pigmented-septated and $\mathbf{B}$, hyaline-unicellular conidial germination of Lasiodiplodia theobromae after 2, 4, 6, 12, and $24 \mathrm{~h}$ of incubation. Bars represent standard error of the mean. Means with the same letter are not significantly different at the 0.05 level. Dotted line represents $50 \%$ germination. 
the role that temperature plays in spore germination. This study represents the first attempt to determine the optimum temperature for conidial germination of Botryosphaeriaceae infecting grapevines. Results of this study show conidial germi- nation to be significantly affected by temperature.

The results of this study on the effect of temperature on germination of conidia of $B$. dothidea are similar to those obtained by both Sutton and Arauz (28) and
Michailides et al. (16). Sutton and Arauz (28) observed the optimum temperature of conidial germination of $B$. dothidea isolates infecting apples to be between 26.7 and $29.5^{\circ} \mathrm{C}$. Michailides et al. (16) showed conidial germination of $B$. dothidea iso-

Table 2. Analysis of fixed effects of isolate, temperature, and time, and their interactions on percentage of conidia germination of each species of Botryosphaeriaceae using a mixed procedure ${ }^{\mathrm{a}}$

\begin{tabular}{|c|c|c|c|c|c|}
\hline Species & Effect & Num df & Den df & $F$ value & $P$ value \\
\hline Botryosphaeria dothidea & $\begin{array}{l}\text { Isolate } \\
\text { Temperature } \\
\text { Time } \\
\text { Temperature*Time } \\
\text { Isolate*Temperature } \\
\text { Isolate*Time } \\
\text { Isolate*Temperature*Time }\end{array}$ & $\begin{array}{r}2 \\
7 \\
4 \\
28 \\
14 \\
8 \\
56\end{array}$ & $\begin{array}{r}2 \\
7 \\
4 \\
28 \\
14 \\
8 \\
56\end{array}$ & $\begin{array}{r}14.52 \\
169.55 \\
203.22 \\
10.12 \\
1.72 \\
0.44 \\
1.16\end{array}$ & $\begin{array}{r}0.0644 \\
<0.0001 \\
<0.0001 \\
<0.0001 \\
0.1609 \\
0.8679 \\
0.2867\end{array}$ \\
\hline Diplodia corticola & $\begin{array}{l}\text { Isolate } \\
\text { Temperature } \\
\text { Time } \\
\text { Temperature*Time } \\
\text { Isolate*Temperature } \\
\text { Isolate*Time } \\
\text { Isolate*Temperature*Time }\end{array}$ & $\begin{array}{r}2 \\
7 \\
4 \\
28 \\
14 \\
8 \\
56\end{array}$ & $\begin{array}{r}2 \\
7 \\
4 \\
28 \\
14 \\
8 \\
56\end{array}$ & $\begin{array}{r}4.16 \\
3,104.78 \\
2,776.22 \\
206.84 \\
1.88 \\
1.15 \\
0.92\end{array}$ & $\begin{array}{r}0.1939 \\
<0.0001 \\
<0.0001 \\
<0.0001 \\
0.1243 \\
0.4218 \\
0.6145\end{array}$ \\
\hline Diplodia mutila & $\begin{array}{l}\text { Isolate } \\
\text { Temperature } \\
\text { Time } \\
\text { Temperature*Time } \\
\text { Isolate*Temperature } \\
\text { Isolate*Time } \\
\text { Isolate*Temperature*Time }\end{array}$ & $\begin{array}{r}1 \\
7 \\
4 \\
28 \\
7 \\
4 \\
28\end{array}$ & $\begin{array}{r}1 \\
7 \\
4 \\
28 \\
7 \\
4 \\
28\end{array}$ & $\begin{array}{r}78.96 \\
2,223.52 \\
2,533.35 \\
131.81 \\
3.47 \\
2.24 \\
0.95\end{array}$ & $\begin{array}{r}0.0713 \\
<0.0001 \\
<0.0001 \\
<0.0001 \\
0.0614 \\
0.2272 \\
0.5543\end{array}$ \\
\hline Diplodia seriata & $\begin{array}{l}\text { Isolate } \\
\text { Temperature } \\
\text { Time } \\
\text { Temperature*Time } \\
\text { Isolate*Temperature } \\
\text { Isolate*Time } \\
\text { Isolate*Temperature*Time }\end{array}$ & $\begin{array}{r}1 \\
7 \\
4 \\
28 \\
7 \\
4 \\
28\end{array}$ & $\begin{array}{r}1 \\
7 \\
4 \\
28 \\
7 \\
4 \\
28\end{array}$ & $\begin{array}{r}137.23 \\
1,698.21 \\
1,662.57 \\
100.97 \\
60.58 \\
24.32 \\
15.61\end{array}$ & $\begin{array}{r}0.0542 \\
<0.0001 \\
<0.0001 \\
<0.0001 \\
<0.0001 \\
0.0046 \\
<0.0001\end{array}$ \\
\hline Dothiorella iberica & $\begin{array}{l}\text { Isolate } \\
\text { Temperature } \\
\text { Time } \\
\text { Temperature*Time } \\
\text { Isolate*Temperature } \\
\text { Isolate*Time } \\
\text { Isolate*Temperature*Time }\end{array}$ & $\begin{array}{r}1 \\
7 \\
4 \\
28 \\
7 \\
4 \\
28\end{array}$ & $\begin{array}{r}1 \\
7 \\
4 \\
28 \\
7 \\
4 \\
28\end{array}$ & $\begin{array}{r}22.83 \\
917.92 \\
1,061.55 \\
222.05 \\
9.01 \\
12.50 \\
9.84\end{array}$ & $\begin{array}{r}0.1313 \\
<0.0001 \\
<0.0001 \\
<0.0001 \\
0.0048 \\
0.0156 \\
<0.0001\end{array}$ \\
\hline $\begin{array}{l}\text { Lasiodiplodia theobromae } \\
\text { (mature) }\end{array}$ & $\begin{array}{l}\text { Isolate } \\
\text { Temperature } \\
\text { Time } \\
\text { Temperature*Time } \\
\text { Isolate*Temperature } \\
\text { Isolate*Time } \\
\text { Isolate*Temperature*Time }\end{array}$ & $\begin{array}{r}2 \\
7 \\
4 \\
28 \\
14 \\
8 \\
56\end{array}$ & $\begin{array}{r}2 \\
7 \\
4 \\
28 \\
14 \\
8 \\
56\end{array}$ & $\begin{array}{r}1.75 \\
67.00 \\
56.66 \\
6.46 \\
0.43 \\
1.71 \\
0.50\end{array}$ & $\begin{array}{r}0.3634 \\
<0.0001 \\
0.0009 \\
<0.0001 \\
0.9362 \\
0.2318 \\
0.9948\end{array}$ \\
\hline $\begin{array}{l}\text { Lasiodiplodia theobromae } \\
\text { (immature) }\end{array}$ & $\begin{array}{l}\text { Isolate } \\
\text { Temperature } \\
\text { Time } \\
\text { Temperature*Time } \\
\text { Isolate*Temperature } \\
\text { Isolate*Time } \\
\text { Isolate*Temperature*Time }\end{array}$ & $\begin{array}{r}2 \\
7 \\
4 \\
28 \\
14 \\
8 \\
56\end{array}$ & $\begin{array}{r}2 \\
7 \\
4 \\
28 \\
14 \\
8 \\
56\end{array}$ & $\begin{array}{r}0.38 \\
62.45 \\
54.55 \\
6.13 \\
0.39 \\
2.01 \\
0.55\end{array}$ & $\begin{array}{r}0.6903 \\
<0.0001 \\
0.0004 \\
<0.0001 \\
0.8991 \\
0.2925 \\
0.9331\end{array}$ \\
\hline Neofusicoccum parvum & $\begin{array}{l}\text { Isolate } \\
\text { Temperature } \\
\text { Time } \\
\text { Temperature*Time } \\
\text { Isolate*Temperature } \\
\text { Isolate*Time } \\
\text { Isolate*Temperature*Time }\end{array}$ & $\begin{array}{r}1 \\
7 \\
4 \\
28 \\
7 \\
4 \\
28\end{array}$ & $\begin{array}{r}1 \\
7 \\
4 \\
28 \\
7 \\
4 \\
28\end{array}$ & $\begin{array}{r}11.97 \\
2,522.42 \\
2,231.43 \\
119.85 \\
0.83 \\
4.46 \\
0.99\end{array}$ & $\begin{array}{r}0.1791 \\
<0.0001 \\
<0.0001 \\
<0.0001 \\
0.5950 \\
0.0885 \\
0.5052\end{array}$ \\
\hline Spencermartinsia viticola & $\begin{array}{l}\text { Isolate } \\
\text { Temperature } \\
\text { Time } \\
\text { Temperature*Time } \\
\text { Isolate*Temperature } \\
\text { Isolate*Time } \\
\text { Isolate*Temperature*Time }\end{array}$ & $\begin{array}{r}2 \\
7 \\
4 \\
28 \\
14 \\
8 \\
56\end{array}$ & $\begin{array}{r}2 \\
7 \\
4 \\
28 \\
14 \\
8 \\
56\end{array}$ & $\begin{array}{r}502.91 \\
2,831.17 \\
2,669.70 \\
172.83 \\
33.43 \\
43.86 \\
26.88\end{array}$ & $\begin{aligned} & 0.0020 \\
&<0.0001 \\
&<0.0001 \\
&<0.0001 \\
&<0.0001 \\
&<0.0001 \\
&<0.0001\end{aligned}$ \\
\hline
\end{tabular}

a Num $\mathrm{df}=$ numerator degrees of freedom, Den $\mathrm{df}=$ denominator degrees of freedom. 
lates infecting pistachio to germinate within 1.5 to $2 \mathrm{~h}$ between 23 and $30^{\circ} \mathrm{C}$. This study showed that $50 \%$ germination of $B$. dothidea isolates infecting grapevines was reached after only $1.7 \mathrm{~h}$ at $25^{\circ} \mathrm{C}$ and after 2.2 and $2.7 \mathrm{~h}$ at 30 and $35^{\circ} \mathrm{C}$, respectively. Moreover, B. dothidea conidia reached $50 \%$ germination after $12 \mathrm{~h}$ at $40^{\circ} \mathrm{C}$. Additionally, previous studies showed isolates of $B$. dothidea from grapevines to be capable of forming colonies at $40^{\circ} \mathrm{C}$ which were characterized by very slow growth (38). However, these results differ from the observations reported by Michailides et al. (16) in which germ tubes of $B$. dothidea isolates from pistachio did not grow more than the length of the spore and failed to develop colonies at 36 and $37^{\circ} \mathrm{C}$. The reasons why $B$. dothidea isolates infecting grapevines germinate and are viable at higher temperatures than those infecting pistachio are not well understood, but the differences could be due to natural variability of the isolates studied.

Foster (8) and Arauz and Sutton (1) showed favorable temperatures for conidial germination of $D$. seriata to range between 12 and $32^{\circ} \mathrm{C}$. Results from our study are similar to those reported by Foster (8) and Arauz and Sutton (1), but D. seriata conidia in our experiments showed a high percent germination $(>80 \%)$ over a broader range of temperatures (10 to $40^{\circ} \mathrm{C}$ ). Arauz and Sutton (1) reported optimum temperature for conidial germination of $D$. seriata isolates from apples to be $24^{\circ} \mathrm{C}$. In our study, optimum temperature for conidial germination of $D$. seriata isolates from grapevines was established at $30^{\circ} \mathrm{C}$; however, $50 \%$ germination was reached within $2 \mathrm{~h}$ incubation at 20, 25, and $35^{\circ} \mathrm{C}$. Additionally, this study showed the ability of $D$. seriata conidia to reach a high percentage of germination at $40^{\circ} \mathrm{C}$, which was unknown from previous studies.

Williamson and Tandon (42) showed mature conidia of $L$. theobromae isolated from banana rot to germinate between 10 and $35^{\circ} \mathrm{C}$ with an optimum temperature of $25^{\circ} \mathrm{C}$. These results differ significantly from the observations recorded in our study. First, optimum temperatures for conidial germination of $L$. theobromae isolates from grapevines in this study were significantly higher $\left(30\right.$ to $\left.40^{\circ} \mathrm{C}\right)$. Additionally, mature conidia of $L$. theobromae from grapevines did not germinate at $10^{\circ} \mathrm{C}$ and showed less than $30 \%$ germination at $15^{\circ} \mathrm{C}$ after $24 \mathrm{~h}$ incubation. Finally, contrary to what was observed by Williamson and Tandon (42), both hyaline and pigmented conidia of $L$. theobromae from grapevines showed high percent germination $(>90 \%)$ at $40^{\circ} \mathrm{C}$. The $L$. theobromae isolates used in this study were from both different host and geographic location with completely different environmental conditions, which could explain the significant variation that temperature has on spore
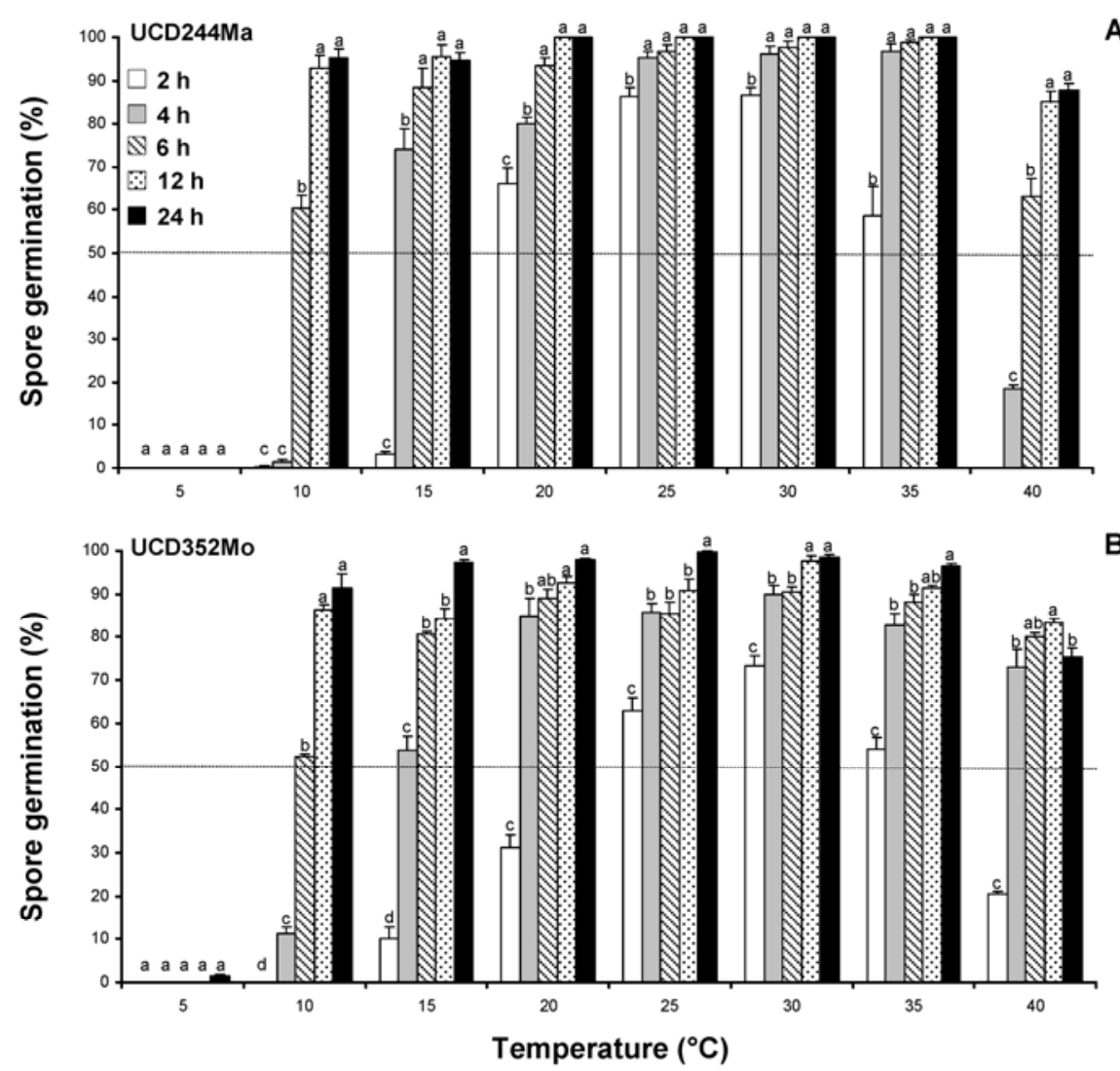

Fig. 3. Effect of temperature on conidial germination of Diplodia seriata isolates A, UCD244Ma and B, UCD352Mo after 2, 4, 6, 12, and $24 \mathrm{~h}$ of incubation. Bars represent standard error of the mean. Means with the same letter are not significantly different at the 0.05 level. Dotted line represents $50 \%$ germination.
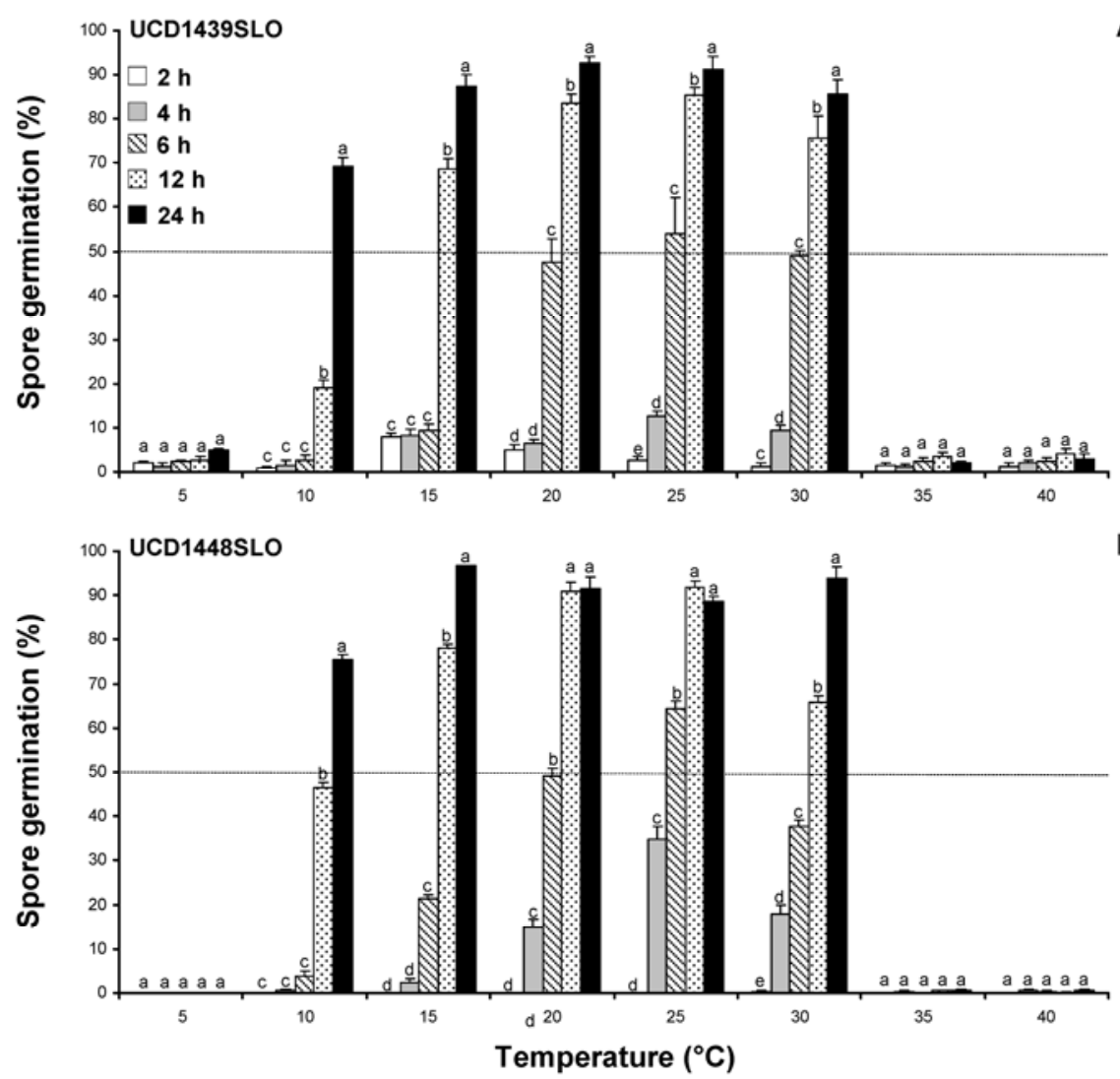

Fig. 4. Effect of temperature on conidial germination of Dothiorella iberica isolates A, UCD1439DLO and B, UCD1448SLO after 2, 4, 6, 12, and $24 \mathrm{~h}$ of incubation. Bars represent standard error of the mean. Means with the same letter are not significantly different at the 0.05 level. Dotted line represents $50 \%$ germination. 
germination between $L$. theobromae isolates infecting grape and banana. Moreover, this study showed the capability of both hyaline-unicellular and pigmentedseptated conidia of $L$. theobromae to reach high levels of germination between 10 and $40^{\circ} \mathrm{C}$ and 15 and $40^{\circ} \mathrm{C}$, respectively. Botryosphaeriaceae species in the genera Diplodia and Lasiodiplodia are characterized by having hyaline conidia when young turning light-brown and/or darkmature $(20,21,30,38)$. Results of this study showed hyaline-unicellular conidia of $L$. theobromae to reach a significantly higher percentage of conidial germination in a shorter incubation time at the same temperatures than the pigmented-septated conidia. Accordingly, conidia of L. theobrown in color and developing septa when

bromae can be considered mature in an early stage when hyaline. Therefore, the development of pigmentation and septa of L. theobromae conidia could be more a consequence of aging than of maturity. However, the biological consequences of this finding are not clear at this time, and more research will be needed in order to determine the role that hyaline conidia could play in disease epidemiology.

Although species of Botryosphaeriaceae infect grapevines worldwide, their geographical distribution has been associated in some grape-growing regions with climatic conditions, especially temperature $(21,30,36,38)$. Previous studies found some correlation between the optimum temperature for mycelium growth of Botryosphaeriaceae species infecting grape-
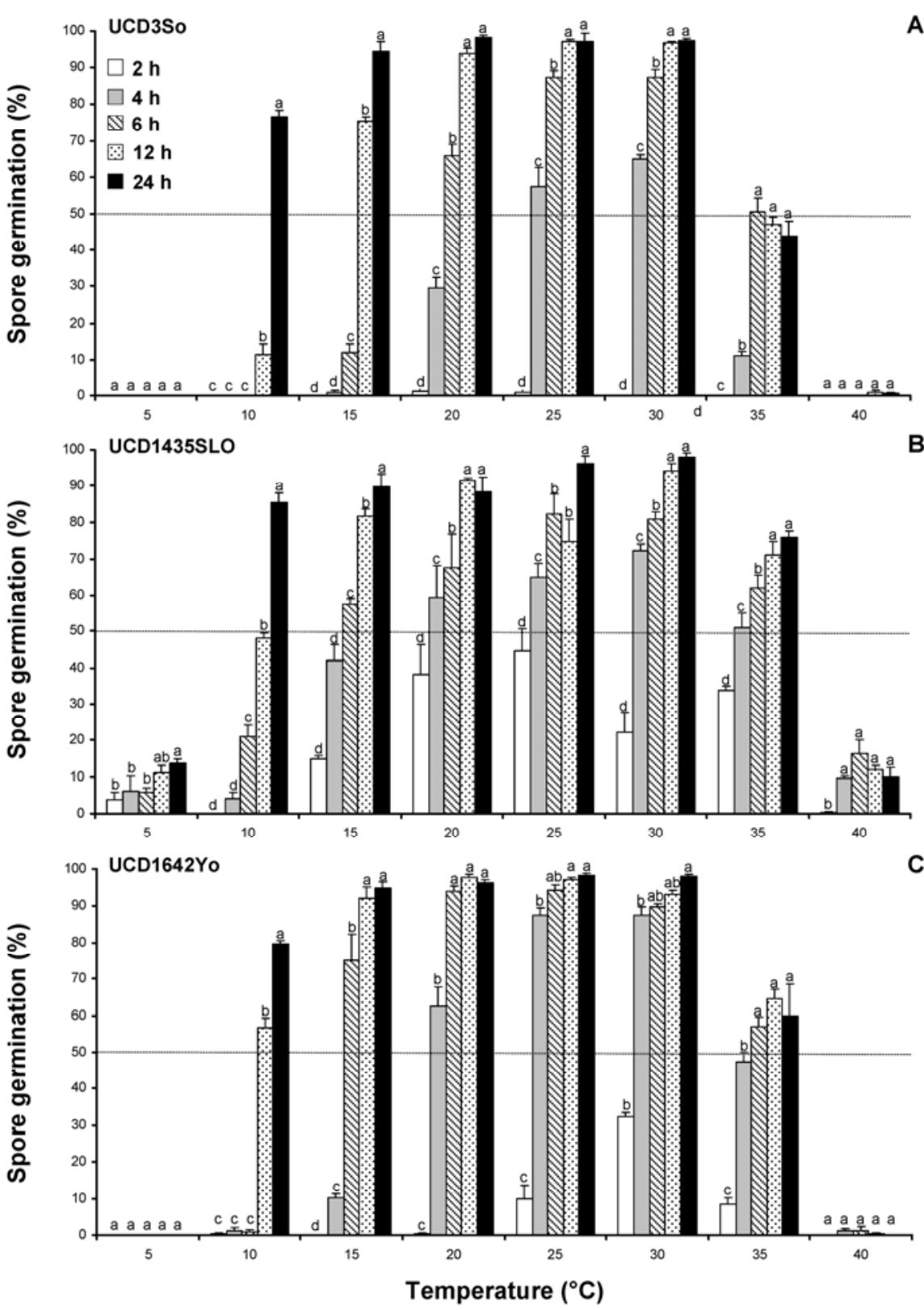

Fig. 5. Effect of temperature on conidial germination of Spencermartinsia viticola isolates A, UCD3SoMa, B, UCD1435SLO, and C, 1642Yo after 2, 4, 6, 12, and 24 h of incubation. Bars represent standard error of the mean. Means with the same letter are not significantly different at the 0.05 level. Dotted line represents $50 \%$ germination. vines and their geographical distribution throughout California (38) and Mexico (36). Results of this study reinforce the idea that the geographical distribution of Botryosphaeriaceae species infecting grapevines may be strongly associated with temperature. This study showed both mature and immature conidia of $L$. theobromae to have the highest optimum temperatures for conidial germination (30 to $40^{\circ} \mathrm{C}$ ) and the lowest germination rate at low temperatures $\left(5\right.$ to $15^{\circ} \mathrm{C}$ ) among all species of Botryosphaeriaceae studied. These results are in agreement with those reported by Copes and Hendrix (6) in which high temperatures $\left(30^{\circ} \mathrm{C}\right)$ were also necessary to reach optimum conidia sporulation of $L$. theobromae isolates infecting apples and peaches. These results may explain why $L$. theobromae is rarely isolated from cold regions and why it is not only the most prevalent but occasionally the only fungus isolated from diseased vines in the warmest grapevine-growing regions of California (38), Mexico (36), and Western Australia (30). Dothiorella iberica conidia showed high germination rate $(>70 \%)$ at low temperatures (10 to $15^{\circ} \mathrm{C}$ ), needed the longest incubation time $(5.86 \mathrm{~h})$ to reach $50 \%$ germination at the optimum temperature $\left(25^{\circ} \mathrm{C}\right)$, and did not germinate at 35 and $40^{\circ} \mathrm{C}$, showing its adaptability to low temperatures. These results, along with those reported by Úrbez-Torres et al. (35) in which Dothiorella iberica showed the lowest optimum temperature $\left(22^{\circ} \mathrm{C}\right)$ for mycelium growth among all species of Botryosphaeriaceae infecting grapevines may explain why this species was mainly isolated from diseased vines in cold grape-growing regions in California. Although this study showed the optimum temperature for conidial germination of $N$. parvum to be $30^{\circ} \mathrm{C}$, the capability of this species to reach over $30 \%$ germination at $5^{\circ} \mathrm{C}$ and 80 and $98 \%$ germination at 10 and $15^{\circ} \mathrm{C}$, respectively, could not only explain why this species is more prevalent in the coldest grapegrowing regions in California (38), but also why it was reported to be the main fungal species associated with grapevine trunk diseases in northeastern American vineyards (23). Among all species of Botryosphaeriaceae used in this study, conidia of D. seriata showed the highest percent germination under the widest range of temperatures $\left(10\right.$ to $40^{\circ} \mathrm{C}$ ), which may explain why this species is probably the most cosmopolitan botryosphaeriaceous fungus infecting grapevines. D. seriata has been reported from over 35 different hosts in most continents (22) and was reported to be the most prevalent botryosphaeriaceous fungus isolated from grapevine cankers in California. Moreover, it is the only botryosphaeriaceous species present in all grapevine-growing regions surveyed throughout California and the United States $(37,38)$. 
Based on both spore trapping $(12,24,32)$ and pruning wound susceptibility studies (34), Botryosphaeriaceae were shown to infect grapevines mainly during dormancy coinciding with the pruning season. Based on the results obtained in this study, conidia of Botryosphaeriaceae species can germinate under a broad range of temperatures including low temperatures (5 to $15^{\circ} \mathrm{C}$ ). Consequently, it is reasonable to hypothesize that conidia can germinate, colonize pruning wounds, and therefore infect grapevines during winter time (dormant season) when the amount of spores in the environment has been shown to be the highest (32). This can be particularly true in grapevine-growing regions of temperate zones with mild winters. During a 3-year study conducted in California vineyards to determine the environmental factors that trigger Botryosphaeriaceae species spore release, average winter temperatures ranged from 8 to $16^{\circ} \mathrm{C}$ depending on the grapevine-region studied (32). The present and other studies have shown successful germination of Botryosphaeriaceae species within the range of those temperatures $(1,28)$. Additionally, Copes and Hendrix (6) showed sporulation of $B$. dothidea, $D$. seriata, and $L$. theobromae to successfully occur over 6 to $30^{\circ} \mathrm{C}$. On the other hand, in grapevine-growing regions with significantly colder winters such as the northeastern United States, a dormancy period of Botryosphaeriaceae species may play an important role in the infection process. Conidial release at temperatures close to and/or below $0^{\circ} \mathrm{C}$ would necessarily need a dormant period until temperatures are more favorable to start germinating. However, previous work showed that even on cold winter days with air temperatures below $0^{\circ} \mathrm{C}$, the temperature on the bark of aspen trees (Populous tremuloides) can be above freezing (43). Consequently, ascospores of the aspen canker pathogen $\mathrm{Hy}$ poxylon mammatum (Wahl.) Mill. (syn. $H$. pruinatum (Klotz.) Cke.) were discharged and could potentially germinate causing new infections in even cold winter days (43). Similar conditions could occur on grape-growing regions with much colder winters than California, allowing possible sporulation, germination, and infection of grapevines by species of Botryosphaeriaceae in cold winter days. Whether or not grapevine bark can present temperatures above freezing in cold winter days and Botryosphaeriaceae conidia are released at temperatures close to $0^{\circ} \mathrm{C}$, present a dormant period, and/or if in regions with colder winters Botryosphaeriaceae infections would occur later in the season (spring) when temperatures are more favorable for conidial germination are still not clear at the present time, and more research is needed in order to clarify these questions. Conidia of Botryosphaeriaceae species infecting grapevines are watersplash dispersed, and thus it is logical to think that besides temperature, moisture can also play a critical role in spore germination. The effect of relative humidity on spore germination has been widely studied in many fungal pathogens including $D$. seriata and $B$. dothidea infecting apples, thus enhancing disease prediction models $(1,28)$. Studies on the effect of relative humidity on both conidia germination and infection process of species of Botryosphaeriaceae infecting grapevines is currently being investigated in our laboratory.

The results presented in this study have added significant information to better understanding of the biology and geographical distribution of Botryosphaeriaceae species infecting grapevines. However, the effect of other environmental factors such as relative humidity and light should not be ignored due to the important role they could play in conidial germination and infection.

\section{ACKNOWLEDGMENTS}

This research was partially funded by the California Competitive Grant Program for Research in Viticulture and Enology, the American Vineyard Foundation, and the Viticulture Consortium West.

\section{LITERATURE CITED}

1. Arauz, L. F., and Sutton, T. B. 1989. Influence of temperature and moisture on germination of ascospores and conidia of Botryosphaeria $o b$ tusa. Phytopathology 79:667-674.

2. Barr, M. E. 1989. The genus Dothidotthia (Botryosphaeriaceae) in North America. Mycotaxon 34:517-526.

3. Bonde, M. R., Berner, D. K., Nester, S. E., and Frederick, R. D. 2007. Effects of temperature on urediniospore germination, germ tube growth, and initiation of infection in soybean by Phakopsora isolates. Phytopathology 97:997-1003.

4. Brooks, F. E., and Ferrin, D. M. 1994. Branch dieback of southern California chaparral vegetation caused by Botryosphaeria dothidea. Phytopathology 84:78-83.

5. Brown, E. A., and Britton, K. O. 1986. Botryosphaeria diseases of apple and peach in the southeastern United States. Plant Dis. 70:480484.

6. Copes, W. E., and Hendrix, F. F., Jr. 2004. Effect of temperature on sporulation of Botryosphaeria dothidea, $B$. obtusa, and $B$. rhodina. Plant Dis. 88:292-296.

7. Espinoza, J. G., Briceño, E. X., Chávez, E. R., Úrbez-Torres, J. R., and Latorre, B. A. 2009. Neofusicoccum spp. associated with stem canker and dieback of blueberry in Chile. Plant Dis. 93:1187-1194.

8. Foster, H. H. 1937. Studies on the pathogenicity of Physalospora obtusa. Phytopathology 27:803-823.

9. Gubler, W. D., Rademacher, M. R., Vasquez, S. V., and Thomas, C. S. 1999. Control of powdery mildew using the UC Davis Powdery Mildew Risk Index. Plant Pathology Online APS Net Feature, January 1999, p. 8. American Phytopathological Society, St. Paul, MN

10. Inderbitzin, P., Bostock, R. M., Trouillas, F. P., and Michailides, T. J. 2010. A six locus phylogeny reveals high species diversity in Botryosphaeriaceae from California almond. Mycologia. In press.

11. Inman, A. R., Kirkpatrick, S. C., Gordon, T. R., and Shaw, D. V. 2008. Limiting effects of low temperature on growth and spore germination in Gibberella circinata, the cause of pitch canker in pine species. Plant Dis. 92:542-545.
12. Kuntzmann, P., Villaume, S., and Bertsch, C. 2009. Conidia dispersal of Diplodia species in a French vineyard. Phytopathol. Mediterr. 48:150-154.

13. Larignon, P., Fulchic, R., Cere, L., and Dubos, B. 2001. Observation on black dead arm in French vineyards. Phytopathol. Mediterr. 40:S336-S342.

14. McDonald, V., Lynch, S., and Eskalen, A 2009. First report of Neofusicoccum australe, N. luteum, and N. parvum associated with avocado branch canker in California. Plant Dis. 93:967.

15. Michailides, T. J. 1991. Pathogenicity, distribution, sources of inoculum, and infection courts of Botryosphaeria dothidea on pistachio. Phytopathology 81:566-573.

16. Michailides, T. J., Morgan, D. P., Grant, J. A. and Olson, W. H. 1992. Shorter sprinkler irrigations reduce Botryosphaeria blight of pistachio. Calif. Agric. 46:28-32.

17. Milholland, R. D. 1988. Macrophoma rot. Page 24 in: Compendium of Grape Diseases. American Phytopathological Society, St. Paul, $\mathrm{MN}$.

18. Milholland, R. D. 1995. Botryosphaeria stem blight. Pages 10-11 in: Compendium of Blueberry and Cranberry Diseases. American Phytopathological Society, St. Paul, MN.

19. Miller, T. C., Gubler, W. D., Geng, S., and Rizzo, D. M. 2003. Effects of temperature and water pressure on conidial germination and lesion expansion of Sphaerotheca macularis $\mathrm{f}$. sp. fragariae. Plant Dis. 87:484-492.

20. Phillips, A. J. L. 2002. Botryosphaeria species associated with disease of grapevines in Portugal. Phytopathol. Mediterr. 41:3-18.

21. Pitt, W. M., Huang, R., Steel, C. C., and Savocchia, S. 2010. Identification, distribution and current taxonomy of Botryosphaeriaceae species associated with grapevine decline in New South Wales and South Australia. Aust. Plant Pathol. 16:258-271.

22. Punitthalingam, E., and Waller, J. M. 1976. Botryosphaeria obtusa. In: Description of Pathogenic Fungi and Bacteria 394. Commonwealth Mycological Institute, Kew, Surrey, England.

23. Rolshausen, P. E., Wilcox, W., and Baumgartner, K. 2010. Distribution and occurrence of fungi associated with grapevine trunk diseases in Northeastern American vineyards. Phytopathol. Mediterr. 49:105.

24. Serra, S., Mannoni, M. A., and Ligios, V. 2007. Studies on the susceptibility of pruning wounds to infection by fungi involved in grapevine wood diseases in Italy. Phytopathol. Mediterr. 47:234-246

25. Siebert, J. B. 2001. Eutypa: The economic toll on vineyards. Wines Vines April: 50-56.

26. Slippers, B., Smit, W. A., Crous, P. W., Coutinho, T. A., Wingfield, B. D., and Wingfield, M. J. 2007. Taxonomy, phylogeny and identification of Botryosphaeriaceae associated with pome and stone fruit tress in South Africa and other regions of the world. Plant Pathol. 56:128-139.

27. Slippers, B., and Wingfield, M. J. 2007. Botryosphaeriaceae as endophytes and latent pathogens of woody plants: Diversity, ecology and impact. Fungal Biol. Rev. 21:90-106.

28. Sutton, T. B., and Arauz, L. F. 1991. Influence of temperature and moisture on germination of ascospores and conidia of Botryosphaeria dothidea. Plant Dis. 75:1146-1149.

29. Tapsoba, H., and Wilson, J. P. 1997. Effects of temperature and light on germination of urediniospores of the pearl millet rust pathogen, Puccinia substriata var. indica. Plant Dis. 81:1049-1052.

30. Taylor, A., Hardy, G. E. St. J., Wood, P., and Burgess, T. 2005. Identification and pathogenicity of Botryosphaeria species associated with grapevine decline in Western Australia 
Aust. Plant Pathol. 34:187-195.

31. Úrbez-Torres, J. R., Adams, P., Kamas, J., and Gubler, W.D. 2009. Identification, incidence, and pathogenicity of fungal species associated with grapevine dieback in Texas. Am. J. Enol. Vitic. 60:497-507.

32. Úrbez-Torres, J. R., Battany, M., Bettiga, L. J., Gispert, C., McGourty, G., Roncoroni, J., Smith, R. J., Verdegaal, P., and Gubler, W. D. 2010. Botryosphaeriaceae species spore trapping studies in California vineyards. Plant Dis. 94:717-724.

33. Úrbez-Torres, J. R., and Gubler, W. D. 2009. Pathogenicity of Botryosphaeriaceae species isolated from grapevine cankers in California. Plant Dis. 93:584-592.

34. Úrbez-Torres, J. R., and Gubler, W. D. 2010. Susceptibility of grapevine pruning wounds to infection by Lasiodiplodia theobromae and Neofusicoccum parvum. Plant Pathol. In press.

35. Úrbez-Torres, J. R., Gubler, W. D., and Luque, J. 2007. First report of Botryosphaeria iberica and $B$. viticola associated with grapevine de- cline in California. Plant Dis. 91:772.

36. Úrbez-Torres, J. R., Leavitt, G. M., Guerrero, J. C., Guevara, J., and Gubler, W. D. 2008. Identification and pathogenicity of Lasiodiplodia theobromae and Diplodia seriata, the causal agents of bot canker disease of grapevines in Mexico. Plant Dis. 92:519-529.

37. Úrbez-Torres, J. R., Leavitt, G. M., Guerrero, J. C., Guevara, J., Striegler, K., Allen, A., and Gubler, W. D. 2007. Identification of fungal pathogens associated with grapevine cankers in the main grape-growing areas of the United States and Mexico. Phytopathol. Mediterr. 46:109-110.

38. Úrbez-Torres, J. R., Leavitt, G. M., Voegel, T. M., and Gubler, W. D. 2006. Identification and distribution of Botryosphaeria spp. associated with grapevine cankers in California. Plant Dis. 90:1490-1503.

39. Úrbez-Torres, J. R., Peduto, F., and Gubler, W. D. 2010. First report of grapevine cankers caused by Lasiodiplodia crassispora and Neofusicoccum mediterraneum in California. Plant Dis. 94:785.
40. Úrbez-Torres, J. R Peduto, F., RooneyLatham, S., and Gubler, W. D. 2010. First report of Diplodia corticola causing grapevine (Vitis vinifera) cankers and trunk cankers and dieback of canyon life oak (Quercus chrysolepis) in California. Plant Dis. 94:785.

41. van Niekerk, J. M., Crous, P. W., Groenewald, J. Z., Fourie, P. H., and Halleen, F. 2004. DNA phylogeny, morphology and pathogenicity of Botryosphaeria species on grapevines. Mycologia 96:781-798.

42. Williamson, D., and Tandon, R. N. 1966. Some pathological studies on Botryodiplodia theobromae Pat. causing banana rot. Mycopathologia 29:245-253.

43. Wood, F. A., and French, D. W. 1986. Hypoxylon canker of aspen: Seasonal development of cankers and ascospores ejection in winter. Phytopathology 55:771-774.

44. Wunderlich, N., Ash, G., Steel, C. C., Rahman, H., and Savochia, S. 2010. Botryosphaeriaceae associated with bunch rot of grapes in South Eastern Australia. Phytopathol. Mediterr. 49:106. 